\title{
PERSISTENCE ON INTERFERON Beta-1b IN MULTIPLE SCLEROSIS: 19-YEAR OF FOLLOW-UP
}

\author{
CARMEN ADELLA SIRBU ${ }^{1 \#}$, CRISTINA FLORENTINA PLEȘA ${ }^{1 \#, ~ M I N E R V A ~ C L A U D I A ~}$ \\ GHINESCU $^{2 *}$, IONUT⿱ CALOIANU ${ }^{1}$, FLORENTINA IONITA-RADU ${ }^{3}$ \\ ${ }^{1}$ Central Military Emergency University Hospital, Clinic of Neurology, 134 Calea Plevnei Street, 010242, Bucharest, \\ Romania \\ ${ }^{2}$ Individual Medical Office Minerva Claudia Ghinescu, 2-4 Școlii Street, 070000, Buftea, Romania \\ ${ }^{3}$ Central Military Emergency University Hospital, Internal Medicine, 134 Calea Plevnei Street, 010242, Bucharest, Romania
}

*corresponding author: ghinescu_minerva@yahoo.com

"Authors with equal contribution.

Manuscript received: February 2020

\begin{abstract}
For multiple sclerosis, a chronic disease, long-term monitoring, persistence, adherence, and safety profile of drugs are important factors for the therapeutic efficacy and quality of life. This study is valuable in this regard, determining the potential factors that contribute to persistence on therapy. Our study aimed to evaluate the persistence to treatment with interferon beta- $1 \mathrm{~b}$ (INF $\beta-1 \mathrm{~b})$ in a group of 113 patients with relapsing-remitting and secondary progressive multiple sclerosis over a 19-year follow-up period. For this, we used descriptive statistical analysis. Correlations were studied using ANOVA and chi-square, Kaplan Meyer survival model; calculations were made in SPSS 26, and graphs in the Excel 2003 version. The age at inclusion was $35.7 \pm 8.6$ years and the average follow-up period was $8.6 \pm 6.1$ years. After 19 years of treatment, $31.9 \%$ of patients continue to receive injectable treatment with INF $\beta-1 b$. Treatment persistence was significantly higher in women than in men. Adverse reactions were low in the group who discontinued therapy. A constant number of patients converted to a progressive form of the disease during the first 13 years of treatment. Treatment with INF $\beta$ - $1 \mathrm{~b}$, although injectable and with a high frequency of administration, has good persistence and a very good long-term safety profile. Women have higher persistence on treatment, and other variables, such as age at onset, EDSS score, and the disease form did not correlate significantly with the persistence rate.
\end{abstract}

\section{Rezumat}

Monitorizarea pe termen lung, persistența, aderența și profilul de siguranță reprezintă factori importanți pentru eficiența terapeutică și calitatea vieții pacienților cu boli cronice precum scleroza multiplă. Valoarea acestui studiu constă în încercarea de a identifica factorii care determină persistența la tratament. Studiul nostru şi-a propus să evalueze persistenţa la tratamentul cu interferon beta-1b (INFß-1b) pentru un grup de 113 pacienți cu scleroză multiplă recurent-remisivă şi secundar-progresivă pe o perioadă de 19 ani. Pentru aceasta, am folosit analize statistice descriptive. Corelaţiile au fost studiate folosind ANOVA și chi-pătrat, modelul Kaplan Meyer, iar calculele au fost făcute în SPSS 26 și graficele în Excel 2003. Vârsta medie la includere a fost de 35,7 $\pm 8,6$ ani, iar perioada medie de urmărire a fost de 8,6 $\pm 6,1$ ani. După 19 ani de tratament, 31,9\% dintre pacienți continuă să primească tratament injectabil cu INF $\beta-1 b$. Persistența la tratament a fost semnificativ mai mare la femei decât la bărbați. Reacțiile adverse au fost scăzute la grupul care a întrerupt terapia. Un număr constant de pacienți s-au convertit la o formă progresivă a bolii în primii 13 ani de tratament. Tratamentul cu INF $\beta-1 b$, deşi injectabil și cu o frecvență mare de administrare, are o persistență bună și un profil de siguranță pe termen lung foarte bun. Femeile au o persistență mai mare la tratament, iar alte variabile, cum ar fi vârsta la debut, scorul EDSS și forma bolii nu s-au corelat semnificativ cu rata persistenței la tratament.

Keywords: Interferon $\beta-1 b$, multiple sclerosis, follow-up, safety, persistence

\section{Introduction}

Multiple sclerosis (MS) is a chronic disease, so therapy plays an essential role. The first drug approved for the treatment of recurrent remissive multiple sclerosis (RRMS) was interferon beta-1b (INFß-1b), in 1993. The drug is injected subcutaneously every other day, for decades, making the withdrawal rate appreciable. In this research, we aimed to see how persistent these patients were on INF $\beta-1 b$, and which were the reasons for discontinuing. The importance of this observational clinical study comes from the long term follow-up with real-life experience.

\section{Materials and Methods}

In Romania, INF $\beta-1 b$ was introduced in the year 2000 for the treatment of RRMS and subsequently, for secondary progressive multiple sclerosis (SPMS) [1]. We performed a retrospective observational study, for 19 years, for patients with MS. 
The main objective was to analyse the persistence (the period when the patient undergoes the indicated treatment) of patients to INF $\beta-1 b$ treatment up to present. Secondary goals were: correlation of persistence with clinical disease form (RRMS, SPMS), disease activity (number of relapses until treatment inclusion and after, Expanded Disability Status Scale-EDSS score on inclusion and upon discontinuation of therapy), adverse reactions, and reasons for drop-out.

113 patients were included between October 1, 2000, and March 31, 2001. All eligible patients (diagnosis of MS, naive patients, age over 18 , EDSS score $\leq 5$ ) were informed and signed a consent about the disease, the medication, the need for follow-up. Patients' medical data were recorded.

The visits were initially performed 1 - 2 times/year and thereafter every 3 months, for clinical control and drug prescription. This allows for good monitoring of patients and increases the quality of care [2]. The EDSS score was calculated annually. The first MRI examination was performed to confirm the diagnosis, the second, one year after starting the therapy to assess its effectiveness and then only for a special clinical condition.

We used descriptive statistics, skewness, kurtosis, and histograms to determine if the numerical variables were normally distributed. Unfortunately, most of the data was bimodal so we have to rely on nonparametric tests. The correlations were studied using a combination of squared tests, one way ANOVA and chi-square. We also studied the effects of certain variables on time spent in the study. We did this using the Kaplan Meyer survival model. All calculations were made in SPSS 26 while the graphs were made in the 2003 Excel version.

Table I

Clinical and demographic features

\begin{tabular}{|c|l|c|}
\hline $\mathbf{1 .}$ & Sex & \\
\hline & \multicolumn{1}{|c|}{ Female } & $75(66 \%)$ \\
\hline & \multicolumn{1}{|c|}{ Male } & $38(33.6 \%)$ \\
\hline $\mathbf{2 .}$ & Year of birth & $1965 \pm 8.5$ \\
\hline $\mathbf{3 .}$ & Age at baseline & $35.7 \pm 8.6$ \\
\hline $\mathbf{4 .}$ & Multiple Sclerosis clinical form & \\
\hline & \multicolumn{1}{|c|}{ Relapsing-Remitting (RR) } & $101(89.4 \%)$ \\
\hline & \multicolumn{1}{|c|}{ Secondary Progressive (SP) } & $12(10.6 \%)$ \\
\hline $\mathbf{5 .}$ & Number of relapses 2 years before inclusion & $2.6 \pm 1.4$ \\
\hline $\mathbf{6 .}$ & Relapses during the follow-up & $0.5 \pm 0.9$ \\
\hline $\mathbf{7 .}$ & Time from diagnostic to treatment initiation (years) & $4.1 \pm 5.3$ \\
\hline $\mathbf{8 .}$ & EDSS scale at baseline & $2.3 \pm 1.3$ \\
\hline $\mathbf{9 .}$ & EDSS scale at drop-out & $3.2 \pm 2.4$ \\
\hline $\mathbf{1 0 .}$ & Mean time for follow-up (years) & $8.6 \pm 6.1$ \\
\hline $\mathbf{1 1 .}$ & Persistence on treatment & \\
\hline & Drop-out rate & $79(69.9 \%)$ \\
\hline & Persistence rate & $34(30.1 \%)$ \\
\hline
\end{tabular}

\section{Results and Discussion}

$89.4 \%$ of patients had RRMS and $10.6 \%$ SPMS. The age at inclusion was $35.7 \pm 8.6$ (Table I). If the number of relapses before starting treatment for the studied group was $2.6 \pm 1.4$, a significant decrease in the number of relapses for patients on treatment was recorded, $0.5 \pm 0.9$. During the first 13 years of treatment, a constant number of patients convert to the progressive form of the disease, after which their number decreases with age. The average follow-up period was $8.6 \pm 6.1$ and $30.1 \%$ of the patients are still on treatment with INF $\beta-1 b$ after 19 years of monitoring. It can be noticed that the discontinuation of the treatment has a bimodal distribution with two peaks: the first in the period $0-1.6$ years and the second in the period 16.6 - 18.2. From Figure 1, it can be seen that the main reason for discontinuing the therapy was the patients' choice.

A smaller percentage discontinued the medication following the diagnostic reassessment. This happened in the first years of follow-up when the experience in diagnosing and treating multiple sclerosis was poor. Reaching score 8 on the EDSS scale is a reason to discontinue the treatment, considering that from this point of the evolution, the treatment is ineffective. Other reasons were planning a pregnancy, change of address or death. We considered noncompliant, patients who did not attend the medical visit and implicitly did not receive medication for at least 3 months. Adverse reactions were low in the group of those who discontinued therapy, the majority consisting of leukopenia or necrosis at the injection site. Among those with psychiatric disorders, depression predominated and was a reason for discontinuation. Females are more in the study after a certain point with $\mathrm{p}$-value = 0.042 (Figure 2). We can say with $95 \%$ confidence that the median persistence of the female population is between 2 and 3.9 years in the study, but for the male is between 0.7 and 1.2 years. 


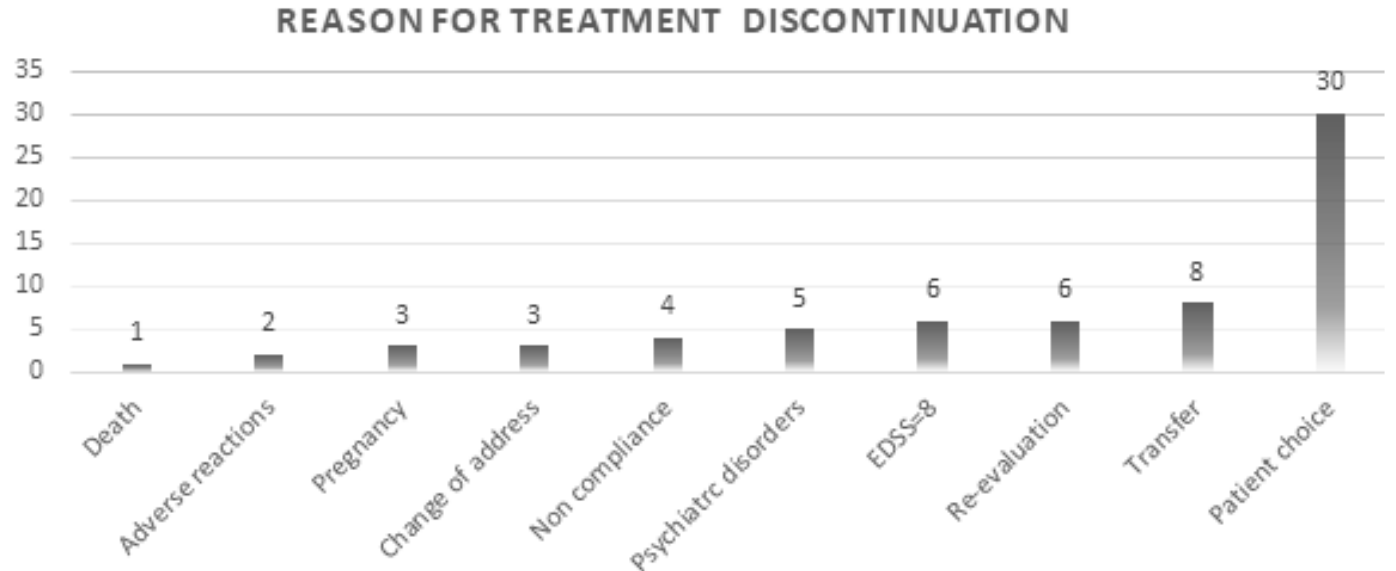

Figure 1.

Reason for treatment discontinuation

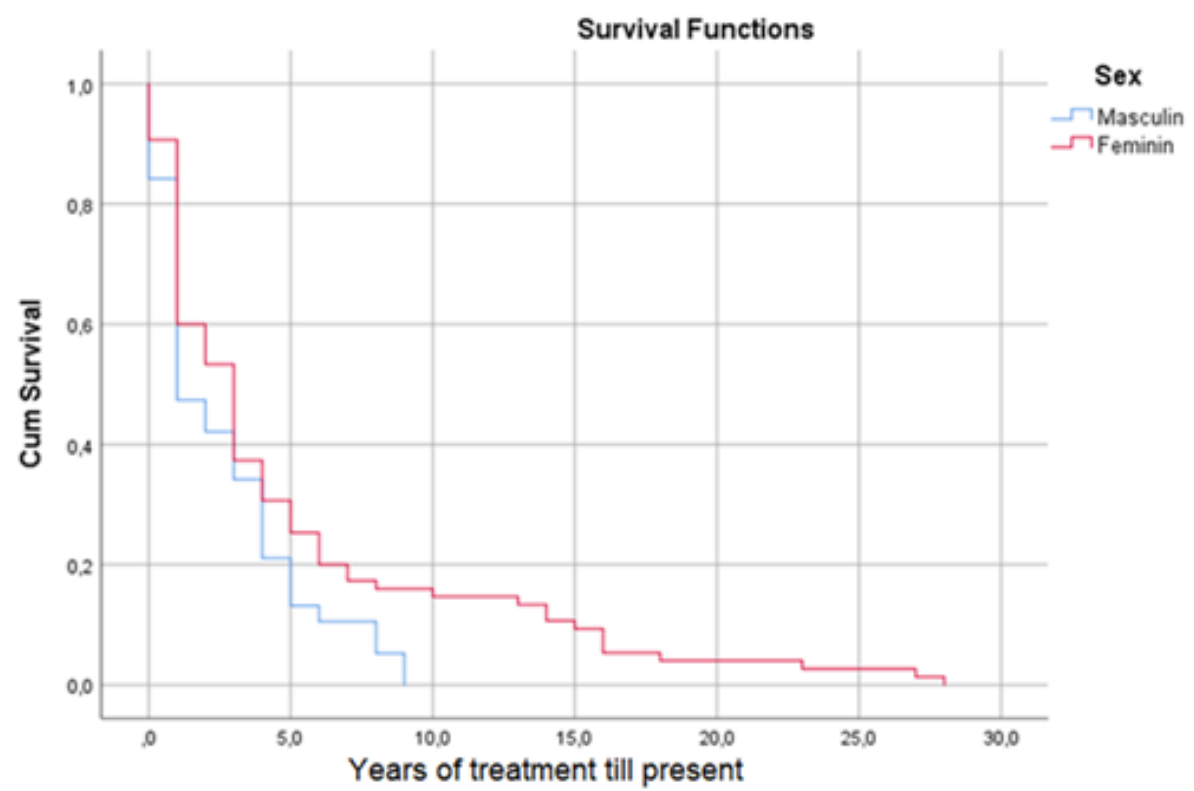

Figure 2.

The graph shows the persistence trends for Females and Males

We could explain the drop relapsing rate after treatment initiation by the efficacy of INF $\beta-1 b$ therapy, omissions in the recordings of patients' relapses and the transformation of RR forms into SP forms, without relapses, conversion occurring after a variable number of years of evolution [3]. A systematic review from 2015 showed that the treatment discontinuation rate is higher in the first $2-3$ years, as shown by our study [4]. Possible explanations for the main reason for discontinuation would be the perceived lack of therapeutic efficacy and the discomfort created by subcutaneous administration of the injections every other day. Compliance represents the patient's behaviour concerning the doctor's recommendations. A Canadian study on 858 patients found that 1 in 10 patients stopped oral disease modifying treatment (DMT) in the first 6 months and 1 in 5 in a year [5]. Adherence to a medication consists of the ratio of the prescribed drug doses to those used by the patient over a specified period (medication possession ratio - MPR) [6]. A study on 2648 patients with MS treated with injectable DMTs, under observation for an average of 31 months, found a $25 \%$ non-adherent percentage, the main reasons were related to forgetting the administration of the vial or to the injection procedure [7]. Another study of 4830 patients with MS treated with first-generation DMTs (interferons and glatiramer acetate) estimated optimum adherence at $76.4 \%$, defined as the proportion of days covered $\geq 80 \%$. This rate is better than in other chronic diseases [8]. In medical research, terms such as adherence, compliance and persistence are understood and used differently. These terms are important especially when talking about chronic diseases. Due to the old used methodologies and their variability, there are differences regarding the results (for example the adherence is between $41 \%$ 
FARMACIA, 2020, Vol. 68, 4

and $88 \%$ ) [9]. The availability of DMTs with oral administration (fingolimod, dimethyl fumarate, teriflunomide and cladribine) increased adherence and persistence to the treatment, compared to the injectable ones. Short and medium-term follow-up of patients revealed superior results for fingolimod in a Canadian study [10]. Most of the studies monitored the persistence and adherence to the treatment of patients with MS for a short duration. This is the only study published to date with a duration of 19 years of follow-up, although it was performed on a relatively small group of patients from all over the country. Only one study monitored 1471 patients with MS and treatment with DMTs, for 18 years, with complete data in $87 \%$ of them. The median time to discontinuation of the first DMT drug was 8.6 years.
Discontinuation or change of treatment was greater for interferons than for Glatiramer Acetate (GA). Patients with a higher EDSS score or below the age of 30 years at the initiation of treatment stopped the medication earlier. Type of the disease and its duration did not influence persistence. Those who started treatment with GA remained more on treatment than those who started with IFNB. 54\% of the patients who stopped the injection resumed oral or infusion treatment [11]. In our research, we did not find significant correlations between treatment persistence and age at disease onset or at treatment inclusion, clinical form (RRMS, SPMS), the number of relapses until treatment inclusion and after, EDSS score at inclusion and at drop-out (Table II).

Table II

Kaplan-Meier and statistical analysis of possible factors associated with non-persistence on IFN $\beta$-1b therapy

\begin{tabular}{|c|c|c|c|c|c|}
\hline Covariate & n & Median time to discontinuation $(\mathrm{CI}=95 \%)$ & $\mathrm{p}$ value & hazard ratio & $\mathrm{p}$ value 2 \\
\hline Clinical form & & & 0.2 & & 0.7 \\
\hline SPMS & 12 & $11.25(6.3-16,1)$ & & 1 & \\
\hline RRMS & 101 & $11.3(10.1-12.6)$ & & \multicolumn{2}{|c|}{$1.1(0.5-2.7)$} \\
\hline Gender & & & 0.042 & & 0.8 \\
\hline Female & 38 & $11.4(9.9-12.9)$ & & 1 & \\
\hline Male & 75 & $11.3(9.1-13.5)$ & & \multicolumn{2}{|c|}{$0.9(0.5-1.5)$} \\
\hline EDSS at baseline & & & 0.12 & & 0.8 \\
\hline$\leq 3$ & 77 & $12.4(11-13.8)$ & & 1 & \\
\hline$>3$ & 36 & $9.4(7-11.7)$ & & \multicolumn{2}{|c|}{$1.7(0.7-2.3)$} \\
\hline EDSS at the last visit & & & 0.7 & & 0.053 \\
\hline$\leq 3$ & 63 & $11.9(9.8-13.2)$ & & 1 & \\
\hline$>3$ & 50 & $11.2(9.3-13.1)$ & & $0.8(0.7-1)$ & \\
\hline
\end{tabular}

The only statistically significant variable was the female gender, with women remaining more on treatment than men. Factors that influence staying on treatment as much as needed are numerous: patient education and culture, doctor/patient/nurse relationship, health system features, patient involvement in medical decision making (as shown in the 2018 AHA guideline), cognitive impairment, depression, other comorbidities, the way the drug has to be administered, adverse reactions, long-term safety profile, increased disability, lack of perception of good results [12-14].

\section{Conclusions}

Treatment with INF $\beta-1 b$ has good persistence and a very good long-term safety profile. $1 / 3$ of the patients remained on treatment (injectable and administered every other day) during 19 years of follow-up. Most patients stopped treatment within the first 2 years after initiation. Treatment discontinuation was not due to adverse reactions. Conversion to the secondary progressive form of multiple sclerosis was mainly during the first 13 years of treatment. Women have a higher persistence on treatment; other variables did not correlate statistically with the persistence rate. Long-term studies are necessary to determine the degree of persistence, adherence and compliance with a chronic injectable, infusion or oral treatment for patients with MS.

\section{Conflict of interest}

The authors declare no conflict of interest.

\section{References}

1. Sirbu CA, Furdu-Lungut E, Plesa CF, Nicolae AC, Dragoi CM, Pharmacological treatment of relapsing remitting multiple sclerosis-where are we?. Farmacia, 2016; 64(5): 651-656.

2. Hobart J, Bowen A, Pepper G, Crofts H, Eberhard L, Berger T, Boyko A, Boz C, Butzkueven H, Celius EG, Drulovic J, Flores J, Horáková D, Lebrun-Frénay C, Marrie RA, Overell J, Piehl F, Rasmussen PV, Sá MJ, Sîrbu CA, Skromne E, Torkildsen Ø, van Pesch V, Vollmer T, Zakaria M, Ziemssen T, Giovannoni G, International consensus on quality standards for brain health-focused care in multiple sclerosis. Mult Scler J., 2019; 25(13): 1809-1818.

3. Cree BA, Gourraud PA, Oksenberg JR, Bevan C, Crabtree-Hartman E, Gelfand JM, Goodin DS, Graves J, Green AJ, Mowry E, Okuda DT, Pelletier D, von Büdingen HC, Zamvil SS, Agrawal A, Caillier S, Ciocca C, Gomez R, Kanner R, Lincoln R, Lizee A, Qualley P, Santaniello A, Suleiman L, Bucci M, Panara V, Papinutto N, Stern WA, Zhu AH, Cutter GR, Baranzini S, Henry RG, Hauser SL, Long-term 
evolution of multiple sclerosis disability in the treatment era. Ann Neurol., 2016; 80(4): 499-510.

4. Butler M, Forte ML, Schwehr N, Carpenter A, Kane RL, Decisional Dilemmas in Discontinuing Prolonged Disease-Modifying Treatment for Multiple Sclerosis [Internet]. Rockville (MD): Agency for Healthcare Research and Quality (US), 2015; Apr. Report No.: 15-EHC012-EF. PMID: 25996027.

5. Setayeshgar S, Kingwell E, Zhu F, Zhang T, Carruthers R, Marrie RA, Evans C, Tremlett H, Persistence and adherence to the new oral disease-modifying therapies for multiple sclerosis: A population-based study. Mult Scler Relat Disord., 2019; 27: 364-369.

6. Menzin J, Caon C, Nichols C, White LA, Friedman M, Pill MW, Narrative review of the literature on adherence to disease-modifying therapies among patients with multiple sclerosis. J Manag Care Pharm., 2013; 19(1 Suppl A): S24-40.

7. Devonshire V, Lapierre Y, Macdonell R, Ramo-Tello C, Patti F, Fontoura P, Suchet L, Hyde R, Balla I, Frohman EM, Kieseier BC, GAP Study Group, The Global Adherence Project (GAP): A multicenter observational study on adherence to disease-modifying therapies in patients with relapsing-remitting multiple sclerosis. Eur J Neurol., 2011; 18(1): 69-77.

8. Evans C, Marrie RA, Zhu F, Leung S, Lu X, Melesse DY, Kingwell E, Zhao Y, Tremlett H, Adherence and persistence to drug therapies for multiple sclerosis: A population-based study. Mult Scler Relat Disord., 2016; 8: 78-85.
9. Morrison A, Stauffer ME, Kaufman AS, Defining medication adherence in individual patients. Patient Prefer Adherence, 2015; 9: 893-897.

10. Johnson KM, Zhou H, Lin F, Ko JJ, Herrera V, RealWorld Adherence and Persistence to Oral DiseaseModifying Therapies in Multiple Sclerosis Patients Over 1 Year. J Manag Care Spec Pharm., 2017; 23(8): 844-852.

11. Zhornitsky S, Greenfield J, Koch MW, Patten SB, Harris C, Wall W, Alikhani K, Burton J, Busche K, Costello F, Davenport JW, Jarvis SE, Lavarato D, Parpal H, Patry DG, Yeung M, Metz LM, Long-term persistence with injectable therapy in relapsing-remitting multiple sclerosis: An 18-year observational cohort study. PLoS One, 2015; 10(4): e0123824: 1-13.

12. Maier S, Motataianu A, Barcutean L, Balint A, Hutanu A, Zoltan B, Stoian A, Romaniuc A, Andone S, Balasa $\mathrm{R}$, Interferon- $\beta$ 1a, an immunomodulator in relapsing remitting multiple sclerosis patients. The effect on proinflammatory cytokines. Farmacia, 2020; 68(1): 65-75.

13. Duquette P, Yeung M, Mouallif S, Nakhaipour HR, Haddad P, Schecter R, A retrospective claims analysis: Compliance and discontinuation rates among Canadian patients with multiple sclerosis treated with diseasemodifying therapies. PLoS One, 2019; 14(1): e0210417: $1-9$

14. Melesse DY, Marrie RA, Blanchard JF, Yu BN, Evans $\mathrm{C}$, Persistence to disease-modifying therapies for multiple sclerosis in a Canadian cohort. Patient Prefer Adherence, 2017; 11: 1093-1101. 